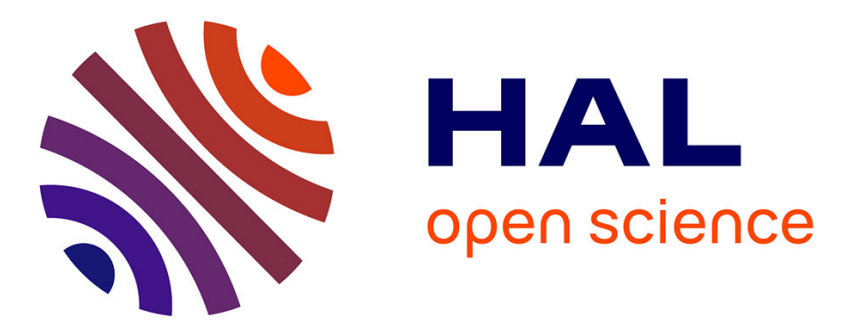

\title{
Ramsey Policies in a Small Open Economy with Sticky Prices and Capital
}

Stéphane Auray, Beatriz de Blaz, Aurélien Eyquem

\section{To cite this version:}

Stéphane Auray, Beatriz de Blaz, Aurélien Eyquem. Ramsey Policies in a Small Open Economy with Sticky Prices and Capital. Journal of Economic Dynamics and Control, 2011, 35 (9), pp. 1531-1546. halshs-00581173

\section{HAL Id: halshs-00581173 https://shs.hal.science/halshs-00581173}

Submitted on 30 Mar 2011

HAL is a multi-disciplinary open access archive for the deposit and dissemination of scientific research documents, whether they are published or not. The documents may come from teaching and research institutions in France or abroad, or from public or private research centers.
L'archive ouverte pluridisciplinaire HAL, est destinée au dépôt et à la diffusion de documents scientifiques de niveau recherche, publiés ou non, émanant des établissements d'enseignement et de recherche français ou étrangers, des laboratoires publics ou privés. 


\section{Ramsey Policies in a Small Open Economy} with Sticky Prices and Capital

Stéphane Auray, Beatriz de Blaz, Aurélien Eyquem

Mars 2011 


\section{GATE Groupe d'Analyse et de Théorie Économique Lyon-St Étienne}

93, chemin des Mouilles 69130 Ecully - France

Tel. +33 (0)4 72866060

Fax $+33(0) 472866090$

6, rue Basse des Rives 42023 Saint-Etienne cedex 02 - France

Tel. +33 (0)4 77421960

Fax. $+33(0) 477421950$

Messagerie électronique / Email : gate@gate.cnrs.fr

Téléchargement / Download : http://www.gate.cnrs.fr - Publications / Working Papers 


\title{
Ramsey Policies in a Small Open Economy with Sticky Prices and Capital*
}

\author{
Stéphane Auray ${ }^{\dagger} \quad$ Beatriz de Blas ${ }^{\ddagger} \quad$ Aurélien Eyquem ${ }^{\S}$
}

February 2011

\begin{abstract}
This paper analyzes jointly optimal fiscal and monetary policies in a small open economy with capital and sticky prices. We allow for trade in consumption goods under perfect international risk sharing. We consider balanced-budget fiscal policies where authorities use distortionary taxes on labor and capital together with monetary policy using the nominal interest rate. First, as long as a symmetric equilibrium is considered, the steady state in an open economy is isomorphic to that of a closed economy. Second, whereas sticky prices allocations are almost indistinguishable from flexible prices allocations, the open economy dimension delivers results that are qualitatively similar to those of a closed economy but with significant quantitative changes. Fluctuations in terms of trade implied by complete international financial markets affect $(i)$ consumption through changes in the consumption price index (CPI), (ii) hours through changes in the CPI-based real wage and (iii) capital accumulation through the relative price of capital goods. These wedges affect the volatility and persistence of optimal tax rates, and resulting allocations are quite different, as compared to a closed economy.
\end{abstract}

Keywords: small open economy, sticky prices, optimal monetary and fiscal policies.

JEL Class.: E52, E62, E63, F41.

*We would like to thank Begoña Domínguez, Cecilia Garcia Peñalosa, Marco Maffezzoli, participants at the Simposio de Análisis Económico 2009, participants at the workshop in honor of Stephen Tunrovsky, Vienna 2010, and participants at the anglo-french-italian workshop 2010 in Marseille for their helpful comments. Beatriz de Blas acknowledges financial support from ECO2008-04073 project of the Spanish MEC.

${ }^{\dagger}$ CNRS - THEMA (UMR 8184), EQUIPPE (EA 4018) - Universités Lille Nord de France (ULCO), Université de Sherbrooke (GREDI) and CIRPEE, Canada. Email: stephane.auray@gmail.com.

¥Universidad Autónoma de Madrid, Departamento de Análisis Económico: T. e H. Económica, Campus de Cantoblanco, 28049 Madrid, Spain. Email: beatriz.deblas@uam.es.

$\S$ Université de Lyon, Lyon, F-69003, France; Ecole Normale Supérieure de Lyon, Lyon, F-69007, France; CNRS, GATE Lyon St Etienne, Ecully, F-69130, France; and GREDI, Université de Sherbrooke, Canada. Email: aurelien.eyquem@ens-lyon.fr. 


\section{Introduction}

It is now well known that it is optimal to use unexpected variations in prices in a flexible prices set-up to smooth taxes. However, when prices are sticky, a trade-off appears between using unexpected inflation to smooth taxes and the fact that adjusting the price level is costly (Schmitt-Grohe and Uribe (2004)). When an open-economy framework is considered, new issues come into play, such as whether to stabilize exchange rate fluctuations or not, and their implications on inflation and welfare (Benigno and de Paoli (2010)).

The literature of optimal taxation following Lucas and Stokey (1983) has established that distorting taxes should be very smooth over time and states of nature. Chari et al. (1991) and Chari and Kehoe (1999) present a set of seminal results in a flexible prices economy with debt, capital income and labor income taxes: $(i)$ capital taxes should be close to zero in the long run, $(i i)$ the ex-ante tax rate on capital should be zero in the short run, (iii) the ex-post tax rate on capital income is highly volatile and bears most of the adjustment after unexpected shocks, together with debt returns, and $(i v)$ labor taxes should consequently be almost kept constant. Restricting the analysis to balanced-budget policies, Stockman (2001), Klein and Rios-Rull (2003) show that most of these results are preserved, including Chamley's (1986) result that states that the capital income tax rate is zero in the long run. The major difference in a balanced budget set-up is that the ex-ante capital income tax rate is not zero anymore, since debt may not be used as a buffer mechanism after unexpected shocks. The ex-ante rate thus fluctuates a lot, and its variance is about two third of the one of the ex-post rate.

Schmitt-Grohe and Uribe (2004) find that the major results about optimal fiscal policy are mostly unchanged in a closed economy when sticky prices are introduced, even though a set-up featuring public debt induces an optimal policy leading to a unit-root on debt, spreading to the policy instruments, including tax rates. However, considering an open economy induces important changes in the optimal policy. Benigno and de Paoli (2010) show that the open-economy dimension introduces fluctuations of terms of trade that directly affect labor supply decisions through the to the so-called terms of trade spillovers 
identified in the monetary policy literature. ${ }^{1}$ According to this literature, policymakers have an incentive to appreciate their terms of trade, so as to increase consumption and lower labor effort. The monetary policy literature has shown that this first order effect can be restated in terms of the second order moments of terms of trade. In the general case, the corresponding policy recommendation is thus to use monetary and/or fiscal instruments to stabilize terms of trade fluctuations, a result recently made clear by Benigno and de Paoli (2010).

Regarding monetary policy, the literature underlines that the optimal policy in a competitive environment with flexible prices is to keep the real interest rate constant. ${ }^{2}$ However, this rule is suboptimal when sticky prices are introduced in models where taxes are not available (see for instance Woodford (2003)). In this case, the optimal monetary policy rule should aim at stabilizing the inflation rate to minimize the distortions implied by nominal rigidities. If taxes and debt are reintroduced in a framework with sticky prices, Correia et al. (2008) show that a combination of taxes can replicate flexible prices allocations, and that monetary policy is not needed in such a case. As already mentioned, policy recommendations are affected by the assumption of trade openness, through the so-called terms of trade spillovers and domestic price stability is outperformed by policies that partly stabilize terms of trade fluctuations (see for instance de Paoli (2009)).

To our knowledge little work has been done on the interaction between monetary and fiscal policy in an open-economy environment with capital. ${ }^{3}$ This may look surprising because the effectiveness and proper conduct of national macroeconomic policies should clearly depend on international linkages between national economies. In particular, previous literature omits capital as an input factor, while introducing this variable seems to be crucial for the results of optimal fiscal policy.

In this paper, we study the dynamic properties of setting taxes and monetary policy

\footnotetext{
${ }^{1}$ See Benigno and Benigno (2003), Corsetti and Pesenti (2001), Corsetti and Pesenti (2005), Devereux and Engel (2007), Obstfled and Rogoff (1998) and Sutherland (2006), among others.

${ }^{2}$ When departing from a cashless economy and introducing money explicitly, the additional recommandation is to set the nominal interest rate equal to zero, a result known as the Friedman rule.

${ }^{3}$ The papers of Ferrero (2009), Galí and Monacelli (2008), and Pappa and Vassilatos (2007), dealing with the optimal fiscal and monetary policy mix in a monetary union affected with idiosynchratic shocks are notable exceptions. However, a multicountry monetary union with one monetary policy and several fiscal instruments is a very specific framework, that significantly differs from ours. In addition those papers do not consider capital accumulation.
} 
optimally in a small open economy with capital and Calvo sticky prices, where households trade consumption goods and engage in complete international asset markets. The setup is a standard new Keynesian DSGE open economy model in the spirit of Galí and Monacelli (2005), in which the government levies distortionary taxes on inputs (capital and labor) to provide individuals with an exogenously determined amount of public good. ${ }^{4}$ An independent regulation authority subsidizes firms to undo the distortions introduced by imperfect competition. We adopt this solution to ease the comparison with the flexible prices competitive economy.

Our approach solves the dual Ramsey problem in the context of a small open economy with capital. We study the optimal taxation system both in the steady state and around this steady state (dynamics). There are several ways in which the open dimension, combined with the presence of nominal rigidities may change some of the traditional results about optimal taxation. First, nominal rigidities may imply departures from the constant interest rate rule. Second, terms of trade spillovers on labor supply, i.e. the impact of changes in terms of trade on households' wealth and labor supply, may change the dynamics of labor taxation. Third, terms of trade fluctuations introduce a distortion in the price of capital goods relative to the price of consumption goods, that may change the dynamics of capital taxation. We contrast the results of our economy with those arising in a closed economy, and with those of an economy with flexible prices.

Our results may be summarized as follows. The open economy does not affect the optimal steady state of the economy, as long as a symmetric steady state is considered, i.e. a steady state where foreign and domestic consumptions are identical. This result does not hold when considering an asymmetric steady state. In this case, the determination of steady state allocations takes into account the terms of trade spillovers, leading to a different steady state tax system. However, to ease comparison with the closed economy case, dynamic results are presented around a symmetric steady state. Along this dimension, in line with Correia et al. (2008), we find that price stickiness affects the optimal policy only marginally both in closed and open economy. Tax rates differs from the flexible prices solution for 2 periods only, and coincide from period 3 and onwards, to minimize the

\footnotetext{
${ }^{4}$ Public debt is not considered since optimal fiscal policies typically induce a unit root on fiscal instruments in an envrionment with sticky prices, making approximation methods used to derive the dynamics of variables around the steady state unreliable.
} 
distortions implied by sticky prices on labor and consumption decisions. The volatility of tax rates is thus increased while their persistence falls, due to large changes in the first periods. Price stickiness therefore delivers qualitative and quantitative properties of allocations, i.e. quantities, that are quite similar to those derived in an economy with flexible prices.

The dynamic properties of the optimal policy in an open economy are quite different. While they are qualitatively the same as those of a closed economy, significant quantitative changes in the volatility and in the persistence of the policy instruments arise. Fluctuations in terms of trade, implied by the presence of complete international financial markets, affect allocations, i.e. the dynamics of consumption, hours and capital all together, through changes in the price of consumption goods and the real wage. Tax rates are both more volatile and more persistent. This result relates to the restatement of the terms of trade spillovers in a problem of terms of trade stabilization and comfort those obtained by Benigno and de Paoli (2010) in a richer framework, that includes capital accumulation.

The paper is structured as follows. The model and its general equilibrium conditions are presented in Section 2. Section 3 describes the parameterization used along the paper. Section 4 reports the results on optimal monetary and fiscal policy both in the steady state and dynamically. The paper concludes with Section 5.

\section{The model}

The model is composed of two areas: the domestic economy and the rest of the world, of size $n$ and $1-n$, respectively. Both areas differ in terms of size. In what follows below, we denote rest of the world variables by an asterisk. In each country, households consume, supply labor and accumulate physical capital that is rented to firms. Firms combine labor and capital to produce differentiated varieties of goods. In each country, a competition regulation authority subsidizes total sales and a government finances an exogenously given amount of public expenditure using labor and capital income taxes, and keeps its budget balanced over time. 


\subsection{Households}

Each country is populated by a continuum of households with infinite life. The domestic representative household maximizes a welfare index

$$
\Omega_{0}(j)=E_{0} \sum_{t=0}^{\infty} \beta^{t} u\left(c_{t}(j), \ell_{t}(j)\right)
$$

subject to the budget constraint

$E_{t}\left\{q_{t, t+1} b_{t+1}(j)\right\}+p_{c, t} c_{t}(j)+p_{t} k_{t}(j)=b_{t}(j)+\Pi_{t}(j)+\left(1-\tau_{\ell, t}\right) w_{t} \ell_{t}(j)+p_{t} r_{k, t} k_{t-1}(j)-\Xi_{t}(j)$,

where $r_{k, t}=1+\left(1-\tau_{k, t}\right)\left(\frac{z_{t}}{p_{t}}-\delta\right)$ and subject to the appropriate transversality condition.

In Equation (1), the parameter $\beta$ is the subjective discount factor, $c_{t}(j)$ is the consumption bundle chosen by the representative agent, $\ell_{t}(j)$ is the quantity of labor competitively supplied. In Equation (2), $w_{t}$ and $z_{t}$ are the nominal wage and return on physical capital rental, $\Pi_{t}(j)=\int_{0}^{n} \Pi_{t}(i, j) d i$ refers to profits paid by domestic firms (operating on monopolistic competition markets), indexed by $i$, to the representative domestic household. The variable $b_{t}(j)$ is a portfolio of state contingent assets held in period $t-1$, which pays in units of domestic aggregate consumption, $q_{t, t+1}$ denotes the stochastic discount factor for one-period ahead nominal payments attached to the portfolio. Further, $p_{c, t}$ and $p_{t}$ denote the consumption price index (CPI) and the production price index (PPI), respectively. $p_{t}$ also denotes the price of capital goods. Finally, $\Xi_{t}$ is a lump-sum tax levied by the competition regulation authority.

The representative household chooses $c_{t}(j), \ell_{t}(j), k_{t}(j)$, and $b_{t+1}(j)$ to maximize utility (1) subject to the budget constraint (2). First order conditions imply

$$
\begin{aligned}
-\frac{u_{\ell, t}}{u_{c, t}}-\left(1-\tau_{\ell, t}\right) \frac{w_{t}}{p_{c, t}} & =0, \\
\beta\left(\frac{u_{c, t+1}}{u_{c, t}}\right)\left(\frac{p_{c, t}}{p_{c, t+1}}\right) & =q_{t, t+1}, \\
q_{t, t+1} \frac{p_{t+1}}{p_{t}} r_{k, t+1} & =1 .
\end{aligned}
$$

Equation (3) is the standard labor supply function, describing the intratemporal tradeoff between consumption and leisure. Equation (4) is the Euler equation relating the 
intertemporal choice of consumption as a function of inflation and the return on the financial portfolio. Denoting $r_{t}=\frac{1}{E_{t}\left\{q_{t, t+1}\right\}}$ as the gross return on a risk-less one-period bond, and taking conditional expectations on both sides of (4), the standard Euler equation writes

$$
r_{t} \beta E_{t}\left\{\left(\frac{u_{c, t+1}}{u_{c, t}}\right)\left(\frac{p_{c, t}}{p_{c, t+1}}\right)\right\}=1 .
$$

Finally, taking conditional expectations on both sides of Equation (5) shows that net returns on disposable assets should be equal in equilibrium

$$
E_{t}\left\{\frac{p_{t+1}}{p_{t}} r_{k, t+1}\right\}=r_{t} .
$$

We follow Benigno and de Paoli (2010) and assume that the aggregate consumption of the representative household is a composite of consumption of goods produced at home $(h)$, and goods produced in the rest of the world $(f)$ according to

$$
c_{t}(j)=\left(\varphi^{\frac{1}{\mu}} c_{h, t}(j)^{\frac{\mu-1}{\mu}}+(1-\varphi)^{\frac{1}{\mu}} c_{f, t}(j)^{\frac{\mu-1}{\mu}}\right)^{\frac{\mu}{\mu-1}}
$$

where $\varphi=1-(1-n) \alpha$ refers to the relative weight of home and foreign goods, which is a function of the size of the domestic economy, $n$, and a measure of trade openness, $\alpha$ (see Corsetti (2006), and Goldberg and Tille (2008)). Symmetrically, the consumption of a representative household in the rest of the world is

$$
c_{t}^{*}(j)=\left(\varphi^{* \frac{1}{\mu}} c_{h, t}^{*}(j)^{\frac{\mu-1}{\mu}}+\left(1-\varphi^{*}\right)^{\frac{1}{\mu}} c_{f, t}^{*}(j)^{\frac{\mu-1}{\mu}}\right)^{\frac{\mu}{\mu-1}},
$$

where $\varphi^{*}=n \alpha$.

We assume that the law of one price holds at the producer level. The companion consumption price indexes are given by

$$
\begin{gathered}
p_{c, t}=\left(\varphi\left(p_{t}\right)^{1-\mu}+(1-\varphi)\left(\varepsilon_{t} p_{t}^{*}\right)^{1-\mu}\right)^{\frac{1}{1-\mu}}, \\
p_{c, t}^{*}=\left(\varphi^{*}\left(\varepsilon_{t}^{-1} p_{t}\right)^{1-\mu}+\left(1-\varphi^{*}\right)\left(p_{t}^{*}\right)^{1-\mu}\right)^{\frac{1}{1-\mu}},
\end{gathered}
$$

where $\varepsilon_{t}$ denotes the nominal exchange rate, expressed as the price of foreign currency in terms of the domestic currency. 
In these expressions, $\mu \geq 1$ is the elasticity of substitution between domestic and foreign goods. Standard Dixit and Stiglitz (1977) consumption subindexes are given by

$$
\begin{aligned}
& c_{h, t}(j)=\left(\left(\frac{1}{n}\right)^{\frac{1}{\theta}} \int_{0}^{n} c_{h, t}(i, j)^{\frac{\theta-1}{\theta}} d i\right)^{\frac{\theta}{\theta-1}}, c_{f, t}(j)=\left(\left(\frac{1}{1-n}\right)^{\frac{1}{\theta}} \int_{n}^{1} c_{f, t}(i, j)^{\frac{\theta-1}{\theta}} d i\right)^{\frac{\theta}{\theta-1}}, \\
& c_{h, t}^{*}(j)=\left(\left(\frac{1}{n}\right)^{\frac{1}{\theta}} \int_{0}^{n} c_{h, t}^{*}(i, j)^{\frac{\theta-1}{\theta}} d i\right)^{\frac{\theta}{\theta-1}}, c_{f, t}^{*}(j)=\left(\left(\frac{1}{1-n}\right)^{\frac{1}{\theta}} \int_{n}^{1} c_{f, t}^{*}(i, j)^{\frac{\theta-1}{\theta}} d i\right)^{\frac{\theta}{\theta-1}},
\end{aligned}
$$

where $c_{h, t}(j)\left(c_{f, t}(j)\right.$, respectively) is the consumption of final goods produced at home (in the rest of the world, respectively) by the representative, and $\theta>1$ is the elasticity of substitution across domestic varieties of final goods.

Accordingly, optimal demands of domestic varieties can be expressed as

$$
c_{h, t}(i, j)=\frac{\varphi}{n}\left(\frac{p_{t}(i)}{p_{t}}\right)^{-\theta}\left(\frac{p_{t}}{p_{c, t}}\right)^{-\mu} c_{t}(j), c_{h, t}^{*}(i, j)=\frac{\varphi^{*}}{n}\left(\frac{p_{t}(i)}{p_{t}}\right)^{-\theta}\left(\frac{p_{t}}{\varepsilon_{t} p_{c, t}^{*}}\right)^{-\mu} c_{t}^{*}(j) .
$$

Households accumulate physical capital according to

$$
x_{t}(j)=k_{t}(j)-(1-\delta) k_{t-1}(j) \text {, }
$$

where $x_{t}(j)$ denotes the investment of household $j$, defined as a bundle of domestic goods, i.e.

$$
x_{t}(j)=\left(\left(\frac{1}{n}\right)^{\frac{1}{\theta}} \int_{0}^{n} x_{t}(i, j)^{\frac{\theta-1}{\theta}} d i\right)^{\frac{\theta}{\theta-1}} .
$$

Optimization implies the following variety demand functions

$$
x_{t}(i, j)=\frac{1}{n}\left(\frac{p_{t}(i)}{p_{t}}\right)^{-\theta} x_{t}(j) .
$$

Finally, let us define terms of trade as

$$
s_{t}=\frac{\varepsilon_{t} p_{t}^{*}}{p_{t}}
$$

This definition is meant to be consistent with the definition of the real exchange rate, $s_{t}^{r}=\frac{\varepsilon_{t} p_{c, t}^{*}}{p_{c, t}}$. Given this notational convention, an increase of $s_{t}$ denotes a deterioration of terms of trade, implying an increase of the competitiveness of goods produced in the domestic economy. 


\subsection{Risk sharing}

Under the assumption of complete international markets of state contingent assets, a relation similar to Equation (4) holds in the rest of the world

$$
\beta\left(\frac{u_{c^{*}, t+1}}{u_{c^{*}, t}}\right)\left(\frac{p_{c, t}^{*}}{p_{c, t+1}^{*}}\right)\left(\frac{\varepsilon_{t}}{\varepsilon_{t+1}}\right)=q_{t, t+1} .
$$

Combining both domestic and foreign Euler equations gives the following risk sharing condition

$$
\frac{u_{c^{*}, t}^{*}}{u_{c, t}}=\epsilon \frac{\varepsilon_{t} p_{c, t}^{*}}{p_{c, t}}=\epsilon s_{t}^{r} .
$$

Equation (7) indicates that relative marginal utilities are related to the real exchange rate up to a constant $\epsilon=\frac{u_{c^{*}}^{*}}{u_{c} s^{r}}$ that captures initial conditions on net foreign assets (see Chari et al. (2002)).

\subsection{Competition regulation authority and government}

The competition regulation authority applies an optimal subsidy on firms' sales $\tau_{y}$, that is financed through a lump-sum (non-distortionary) tax $\Xi_{t}$

$$
\int_{0}^{n} \Xi_{t}(j) d j+\tau_{y} \int_{0}^{n} p_{t}(i) y_{t}(i) d i=0
$$

Public expenditure of the government is composed of domestic varieties only

$$
g_{t}=\left(\left(\frac{1}{n}\right)^{\frac{1}{\theta}} \int_{0}^{n} g_{t}(i)^{\frac{\theta-1}{\theta}} d i\right)^{\frac{\theta}{\theta-1}}
$$

where

$$
g_{t+1}=\left(1-\rho_{g}\right) g+\rho_{g} g_{t}+\xi_{g, t+1}
$$

with $\xi_{g, t+1}$ being an iid innovation with constant variance. The government has access to distorting taxes on inputs (labor and capital) to finance the exogenous stream of public spending. We only allow for balanced-budget policies, therefore the budget constraint of authorities in the domestic economy, expressed in nominal terms, is

$$
\tau_{\ell, t} w_{t} \ell_{t}+\tau_{k, t}\left(z_{t}-\delta\right) k_{t-1}=p_{t} g_{t}
$$

where $\ell_{t}=\int_{0}^{n} \ell_{t}(j) d j, k_{t-1}=\int_{0}^{n} k_{t-1}(j) d j$ and $p_{t} g_{t}=\int_{0}^{n} p_{t}(i) g_{t}(i) d i$. 


\subsection{Firms}

Firms, indexed by $i$, produce varieties $y_{t}(i)$ using domestic labor, $l_{t}(i)$, and physical capital, $k_{t-1}(i)$, according to the following production function:

$$
y_{t}(i)=a_{t} k_{t-1}(i)^{\phi} l_{t}(i)^{1-\phi} \text {. }
$$

The total factor productivity, $a_{t}$, evolves according to

$$
a_{t+1}=\left(1-\rho_{a}\right) a+\rho_{a} a_{t}+\xi_{a, t+1},
$$

where $\xi_{a, t+1}$ is an iid innovation with constant variance. Input prices are related by the following efficiency condition

$$
\phi w_{t} l_{t}(i)=(1-\phi) z_{t} k_{t-1}(i)
$$

and the nominal marginal cost, which is the same for all firms, writes

$$
m c_{t}(i)=m c_{t}=\frac{z_{t}^{\phi} w_{t}^{1-\phi}}{\phi^{\phi}(1-\phi)^{1-\phi}} a_{t}^{-1} .
$$

Production prices are governed by Calvo (1983) pricing contracts. Only a fraction 1 $\eta$ of randomly selected domestic firms is allowed to set new prices each period. The corresponding optimal price set by a firm allowed to reset is

$$
\bar{p}_{t}(i)=\frac{\theta}{(\theta-1)\left(1-\tau_{y}\right)} \frac{\sum_{v=0}^{\infty}(\eta \beta)^{v} E_{t}\left\{\lambda_{t+v} y_{t+v}(i) m c_{t+v}\right\}}{\sum_{v=0}^{\infty}(\eta \beta)^{v} E_{t}\left\{\lambda_{t+v} y_{t+v}(i)\right\}},
$$

where $\lambda_{t}$ is the Lagrange multiplier associated with the representative household's budget constraint and $y_{t}(i)$ is the aggregate demand addressed to firm $i$

$$
y_{t}(i)=c_{h, t}(i)+c_{h, t}^{*}(i)+x_{t}(i)+g_{t}(i),
$$

In this expression, $c_{h, t}(i)=\int_{0}^{n} c_{h, t}(i, j) d j, c_{h, t}^{*}(i)=\int_{n}^{1} c_{h, t}^{*}(i, j) d j$, and $x_{t}(i)=\int_{0}^{n} x_{t}(i, j) d j$. In addition, $\frac{\theta}{(\theta-1)\left(1-\tau_{y}\right)}$ is the steady state mark-up indicating the distortion caused by monopolistic competition in final goods markets.

Aggregating among firms and assuming that Calvo producers set the same price when free to reset, the aggregate production price index is

$$
p_{t}=\left((1-\eta) \bar{p}_{t}(i)^{1-\theta}+\eta p_{t-1}^{1-\theta}\right)^{\frac{1}{1-\theta}} .
$$


Defining the PPI inflation rate and the CPI inflation rate as respectively as $\pi_{t}=\frac{p_{t}}{p_{t-1}}$ and $\pi_{t}=\frac{p_{c, t}}{p_{c, t-1}}$, the PPI inflation rate evolves according to ${ }^{5}$

$$
\eta \pi_{t}^{\theta-1}+(1-\eta)\left(\frac{\theta}{(\theta-1)\left(1-\tau_{y}\right)} \frac{v_{1, t}}{v_{2, t}}\right)^{1-\theta}=1,
$$

where

$$
\begin{gathered}
v_{1, t}-\eta \beta E_{t}\left\{v_{1, t+1} \pi_{t+1}^{1+\theta} \pi_{c, t+1}^{-1}\right\}=u_{c, t} y_{t} \frac{m c_{t}}{p_{t}} \\
v_{2, t}-\eta \beta E_{t}\left\{v_{2, t+1} \pi_{t+1}^{\theta} \pi_{c, t+1}^{-1}\right\}=u_{c, t} y_{t} .
\end{gathered}
$$

Finally, the dispersion of production prices, $\Upsilon_{t}=\int_{0}^{1}\left[\frac{p_{t}(i)}{p_{t}}\right]^{-\theta} d i \geq 1$, is given by

$$
\Upsilon_{t}=\eta \Upsilon_{t-1} \pi_{t}^{\theta}+(1-\eta)\left(\frac{\theta}{(\theta-1)\left(1-\tau_{y}\right)} \frac{v_{1, t}}{v_{2, t}}\right)^{-\theta}
$$

\subsection{Equilibrium}

We focus on the case of a small open economy, i.e. $n \rightarrow 0$, in deriving the optimal monetary and fiscal policy. One implication is that CPIs can be expressed as

$$
p_{c, t}^{*}=p_{t}^{*}, \quad \text { and } \quad p_{c, t}=\left((1-\alpha)\left(p_{t}\right)^{1-\mu}+\alpha\left(\varepsilon_{t} p_{t}^{*}\right)^{1-\mu}\right)^{\frac{1}{1-\mu}} .
$$

Let us define aggregate output as $y_{t}=\left(\left(\frac{1}{n}\right)^{\frac{1}{\theta}} \int_{0}^{n} y_{t}(i)^{\frac{\theta-1}{\theta}} d i\right)^{\frac{\theta}{\theta-1}}$. The final goods market thus clears according to

$$
y_{t}=(1-\alpha)\left(1-\alpha+\alpha s_{t}^{1-\mu}\right)^{\frac{\mu}{1-\mu}} c_{t}+\alpha s_{t}^{\mu} c^{*}+x_{t}+g_{t},
$$

where $c^{*}$ is exogenous and constant. Finally, the labor market clearing condition is

$$
\int_{0}^{n} l_{t}(i) d i=\int_{0}^{n} \ell_{t}(j) d j=\ell_{t}
$$

the capital market clearing condition is

$$
\int_{0}^{n} k_{t}(i) d i=\int_{0}^{n} k_{t}(j) d j=k_{t}
$$

and the aggregate production is given by

$$
y_{t}=\Upsilon_{t}^{-1} a_{t} k_{t-1}^{\phi} \ell_{t}^{1-\phi}
$$

\footnotetext{
${ }^{5}$ See Appendix A for the derivation of these conditions.
} 
Finally, restoring the competitive steady state mark-up requires that the regulation authority sets

$$
\tau_{y}=(1-\theta)^{-1}
$$

Let $\left\{\mathcal{R}_{t}\right\}_{t=0}^{\infty}=\left\{r_{t}, \tau_{n, t}, \tau_{k, t}\right\}_{t=0}^{\infty}$ be a sequence of monetary and fiscal policies.

Let $\left\{\mathcal{S}_{t}\right\}_{t=0}^{\infty}=\left\{a_{t}, g_{t}\right\}_{t=0}^{\infty}$ be a sequence of exogenous shocks.

Let $\left\{\mathcal{Q}_{t}\right\}_{t=0}^{\infty}=\left\{y_{t}, n_{t}, c_{t}, k_{t}\right\}_{t=0}^{\infty}$ be a sequence of quantities.

Let $\left\{\mathcal{P}_{t}\right\}_{t=0}^{\infty}=\left\{\pi_{t}, p_{t}, p_{c, t}, w_{t}, z_{t}, m c_{t}, s_{t}, v_{1, t}, v_{2, t}, \Upsilon_{t}\right\}_{t=0}^{\infty}$ be a sequence of prices.

Definition An equilibrium is defined as an allocation $\left\{\mathcal{Q}_{t}\right\}_{t=0}^{\infty}$ and a sequence of prices $\left\{\mathcal{P}_{t}\right\}_{t=0}^{\infty}$ such that, (i) for a given sequence of prices $\left\{\mathcal{P}_{t}\right\}_{t=0}^{\infty}$, shocks $\left\{\mathcal{S}_{t}\right\}_{t=0}^{\infty}$ and a given policy $\left\{\mathcal{R}_{t}\right\}_{t=0}^{\infty}$, the sequence $\left\{\mathcal{Q}_{t}\right\}_{t=0}^{\infty}$ satisfies households first-order conditions (including the transversality conditions), maximizes firms profits and balances the budget of the government; (ii) for a given sequence of quantities $\left\{\mathcal{P}_{t}\right\}_{t=0}^{\infty}$, shocks $\left\{\mathcal{S}_{t}\right\}_{t=0}^{\infty}$ and a given policy $\left\{\mathcal{R}_{t}\right\}_{t=0}^{\infty}$, the sequence $\left\{\mathcal{P}_{t}\right\}_{t=0}^{\infty}$ clears goods markets and factors markets.

\section{Parameterization}

Before turning to the analysis of the optimal monetary and fiscal policies, we assign numerical values to our deep parameters to proceed with the numerical simulations.

Utility function. We adopt the following functional form of the utility function:

$$
u\left(c_{t}(j), n_{t}(j)\right)=\frac{c_{t}(j)^{1-\sigma}}{1-\sigma}-\frac{\ell_{t}(j)^{1+\psi}}{1+\psi} .
$$

Preferences. We consider a quarterly set-up. The subjective discount factor, $\beta$, is thus equal to 0.988 , consistent with an average annual real interest rate of $5 \%$ in the steady state. The inverse of the intertemporal elasticity of consumption is $\sigma=2$ as in Corsetti et al. (2008). We set the inverse of the elasticity of labor supply with respect to wages, $\psi$, equal to 1 . This value lies within the interval proposed by Canzoneri et al. (2007). The elasticity of substitution between domestic and foreign goods is $\mu=1.5$ as in Backus and Kehoe (1994). The elasticity of substitution across domestic varieties of final goods is set to $\theta=7$, in accordance with Rotemberg and Woodford (1997). 
Technology. The share of capital income in the GDP is $\phi=0.36$. The depreciation rate $\delta$ is assumed to be $10 \%$ annually, i.e. $\delta=0.025$. The degree of price stickiness, i.e. the Calvo parameter, is $\eta=0.75$, implying an average duration of 4 quarters for prices.

Shocks. The characteristics of productivity and public expenditure innovations are $\sigma\left(\xi_{a}\right)=0.007$ and $\sigma\left(\xi_{g}\right)=0.01$. The persistence of shocks is set to $\rho_{a}=\rho_{g}=0.9$. We also calibrate the steady state value public expenditure to represent $25 \%$ of the GDP, i.e. $\kappa=\frac{g}{y}=0.25$.

Openness. Finally, the degree of trade openness is $\alpha=0$ in the case of a closed economy and $\alpha=0.3$ in the case of an open economy. This value is in between the interval of parameters suggested by Galí and Monacelli (2005) and Pappa and Vassilatos (2007). In the case of an open economy, we consider zero initial net foreign assets, i.e. $\epsilon=1$.

\section{Optimal monetary and fiscal policy}

In this section, we present the Ramsey problem, and comment the implied results both in the steady state and around the steady state when unexpected shocks hit the economy.

\subsection{The Ramsey problem}

We solve the dual form of the optimal monetary and fiscal policy problem, that consists in finding the sequence $\left\{\tau_{\ell, t}, \tau_{k, t}, r_{t}\right\}_{t=0}^{\infty}$ associated with the equilibrium described above, that maximizes individuals' welfare. The Ramsey problem thus writes

$$
\underset{\tau_{\ell, t}, \tau_{k, t}, r_{t}}{\operatorname{Max}} E_{0} \sum_{t=0}^{\infty} \beta^{t} \int_{0}^{n} u\left(c_{t}(j), \ell_{t}(j)\right) d j
$$

subject to the constraint that the resulting equilibrium is compatible with the equilibrium described by Eqs. (8)-(19) in Appendix B. This problem is known to result in time-inconsistent policies, as authorities may choose their policy instruments after agents have formed their expectations about forward key variables, such as the inflation rate, and therefore may take advantage of this situation in period zero. As a consequence, from period one and onwards, authorities have an incentive to change their optimal policy since agents now take into account prior commitments when forming their expectations. Therefore, to avoid such inconsistency issues, we adopt the timeless perspective (see Woodford 
(2000)) and assume that the optimization problem is constrained by some former prior commitment, that is consistent with the optimal commitment chosen for period one and onwards. ${ }^{6}$ We thus solve our dynamic Ramsey program and analyze its dynamic properties when the economy is closed or open respectively. ${ }^{7}$

\subsection{Steady state results}

As shown in Appendix C, relations characterizing a decentralized equilibrium allow to determine all variables in the steady state once $\left(\pi, \tau_{k}\right)$ is determined. The latter is given by the steady state resolution of the dynamic conditions implied by the Ramsey problem. Given the functional forms of the model, analytical derivations of the Ramsey conditions in the steady state are cumbersome. Thus, we provide some simulation-based results to discuss the properties of the steady state tax rates obtained by solving the dynamic Ramsey problem.

In particular, we stress the importance of domestic consumption in the steady state compared to foreign consumption in determining the steady state tax rates. Due to the risk sharing condition, whether a country consumes more or less than the rest of the world in the steady state implies that his currency is depreciated or appreciated in real terms. In particular, given that $\epsilon=1$, and that $c^{*}$ is exogenous, the definition of $\epsilon=\left(\frac{c}{c^{*}}\right)^{\sigma}\left(\alpha+(1-\alpha) s^{1-\mu}\right)^{\frac{1}{1-\mu}}$ imposes the value of terms of trade in the steady state. Authorities are thus unable to manipulate terms of trade in the steady state. The steady state conditions describing the decentralized equilibrium show that steady state relative consumptions have an impact on the steady state level of consumption, for a given steady state level of inflation and of the capital income tax rate (which, again derive from the dynamic conditions). Indeed, as shown in Appendix C, the steady state domestic consumption as a function of $\left(\pi, \tau_{k}\right)$ writes

$$
c^{\frac{\sigma+\psi}{\psi}} f_{2}(c)^{-\frac{1}{\psi}} f_{3}(c)=\chi_{1} \chi_{2}^{\frac{1}{\psi}},
$$

\footnotetext{
${ }^{6}$ Formally, the time inconsistency problem arises from the inconsistency between initial conditions and dynamic optimal conditions. The timeless perspective assumes that the equilibrium is given by dynamic conditions only, that describe the transition between period $t$ and $t+1$, while initial conditions are assumed away.

${ }^{7}$ We solve the Ramsey problem analytically (in level) using Matlab's symbolic toolbox, and use Dynare's first-order approximation algorithm to simulate the model numerically. As shown in the literature (for instance Benigno and Woodford (2005)), this approach delivers an accurate approximation of the policy problem.
} 
where

$$
\begin{gathered}
f_{2}(c)=\left(\left((1-\alpha)\left(\frac{c}{c^{*}}\right)^{\sigma(\mu-1)}\right)\left(\left(\frac{c}{c^{*}}\right)^{\sigma(\mu-1)}-\alpha\right)^{-1}\right)^{\frac{1}{\mu-1}} \\
f_{3}(c)=(1-\alpha) f_{2}(c)^{-\mu}+\alpha \frac{c}{c^{*}}\left((1-\alpha)^{-1}\left(\left(\frac{c}{c^{*}}\right)^{\sigma(\mu-1)}-\alpha\right)\right)^{\frac{\mu}{\mu-1}}
\end{gathered}
$$

and where

$$
\begin{gathered}
\chi_{1}=(1-\kappa) \Upsilon(\pi)^{-1} h\left(\tau_{k}, m c(\pi)\right)^{\phi}-\delta h\left(\tau_{k}, m c(\pi)\right) \\
\chi_{2}=\left(1-\tau_{\ell}\left(\tau_{k}, m c(\pi)\right)\right) m c(\pi)(1-\phi) h\left(\tau_{k}, m c(\pi)\right)^{\phi}
\end{gathered}
$$

are some functions of the optimal tax rate on capital income $\left(\tau_{k}\right)$ and the optimal inflation rate $(\pi)$, that do not depend on the degree of trade openness.

In a closed economy $(\alpha=0)$, or when consumption in the small open economy is identical to consumption in the rest of the world, $f_{2}(c)=f_{3}(c)=1$. In this case, the steady state of the Ramsey problem is isomorphic to the closed economy equilibrium with flexible prices. As in Chari et al. (1991), the steady state value of $\tau_{k}$ returned by the dynamic system is $\tau_{k}=0$ and the steady state inflation rate is $\pi=1$. Consequently, the implied labor income tax rate is $\tau_{\ell}=\kappa(1-\phi)^{-1}$.

The way the open economy affects the steady state tax systems depends on steady state relative consumptions. If one considers an economy with $c>c^{*}$, then the currency of the small open economy is depreciated in real terms, i.e. $s>1$ due to the risk sharing condition. The CPI is thus higher than the PPI, which, with an unchanged tax system, leads households to consume less, build a larger stock of capital and supply more labor. To see this, notice that $f_{2}<1$ and $f_{3}>1$ as long as $c>c^{*}$ so that $f_{2}(c)^{-\frac{1}{\psi}} f_{3}(c)>1$ as long as $\psi>0$, which implies that consumption is lower in the open economy than in a closed economy ceteris paribus, i.e. for the same steady state tax rate on capital income and inflation rate.

In this context, the attitude of the central planner consists in raising the tax rate on labor income and to subsidize capital. Eventhough subsidizing capital reduces consumption, the central planner seeks to limit the increase in the level of labor supply and to increase the capital stock. The objective is to obtain a higher capital to labor ratio and therefore 
a higher PPI-based real wage, to limit the drop in consumption together with a limited increase in labor supply. Considering an open economy where $c<c^{*}$ generates opposite effects. In this case, the relative price of capital goods increases, which tends to lower the capital to labor ratio, and to increase the steady state capital rental. The central planner thus finds it optimal to tax capital, in order to keep the Euler equation undistorted. Table 1 illustrates these effects and reports the steady state values of key variables (the tax rates, inflation, output, consumption, hours, the capital stock, and the terms of trade) arising from solving dynamic conditions from the Ramsey problem in the steady state. Table 1 reports three cases: $(i)$ a steady state where $c>c^{*}$ (first row), (ii) a steady state where $c<c^{*}$ (second row) and (iii) the symmetric case where $c=c^{*}$, where the steady state is isomorphic to the case of a closed economy.

Table 1: Steady states implied by optimal policies for different relative consumptions ratios

\begin{tabular}{lccc}
\hline \hline & $\Lambda^{a}=1.01$ & $\Lambda=0.99$ & $\Lambda=1.00$ \\
\hline \hline$\tau_{k}$ & -0.1914 & 0.1489 & 0.0000 \\
$\tau_{\ell}$ & 0.4218 & 0.3602 & 0.3906 \\
$\pi$ & 1.0000 & 1.0000 & 1.0000 \\
$y$ & 2.7735 & 2.6077 & 2.6906 \\
$c$ & 1.3452 & 1.3839 & 1.3660 \\
$n$ & 0.7499 & 0.7499 & 0.7499 \\
$k$ & 28.369 & 23.905 & 26.076 \\
$s$ & 1.0291 & 0.9719 & 1.0000 \\
\hline \hline$a: \Lambda=\frac{c}{c^{*}}$ & &
\end{tabular}

Even for small differences in relative consumptions, the optimal steady state tax rate implied by the dynamic Ramsey problem is not zero anymore. For instance, when domestic consumption is $1 \%$ higher than abroad, the optimal capital income subsidy is $19.14 \%$, implying a $42.18 \%$ labor income tax rate. It is about 3 percentage points higher than in the symmetric case, in order to balance the budget. In the opposite case, when domestic consumption is $1 \%$ lower than abroad, the optimal tax rate on capital income is positive and equal to $14.89 \%$, allowing the labor income tax rate to be 3 percentage points lower than in the symmetric case. Openness thus matters considerably in determining the optimal long run (steady state) tax system, as soon as asymmetry is considered in a set-up 
with a balanced budget.

In the remaining of the paper, however, we focus on the case of a symmetric steady state only. For the sake of comparability between closed and open economies, all optimal policies are computed around the same steady state, and the analysis focuses on dynamic differences only. This is done in the next subsection.

\subsection{Dynamics}

In this section, we characterize the dynamic properties of the model when the economy is closed with flexible (situation I) and sticky prices (situation II), and contrast them with those arising in an open economy with flexible (situation III) and sticky prices (situation IV). The main picture that emerges is the following. On the one hand, the assumption of sticky prices does not make a big difference with respect to standard results when prices are flexible both qualitatively and quantitatively, in the sense that optimal policies under sticky prices tend to replicate the flexible price allocations, both in the open and the closed economy. On the other hand, optimal policies in the open economy have qualitatively similar implications than in the closed economy but significant quantitative differences arise.

First, Figure 1 plots the Impulse Response Functions (IRFs hereafter) of the economy after a positive productivity shock. We report the dynamics of these variables in the four situations considered.

Qualitatively, Figure 1 presents standard results since a productivity shock increases output, consumption, capital stock, hours, and the real interest rate. The optimal tax mix is to increase labor income taxes to limit the increase in hours and to decrease capital income taxes, i.e. applying a negative capital income tax rate, to subsidize capital accumulation and therefore limit the increase in consumption. The labor income tax rate varies little while the capital income tax rate exhibits very large variations. Stockman (2001) finds that capital income taxes are negatively correlated with productivity shocks while labor income taxes are positively correlated with productivity shocks. In his view, when the government faces balanced-budget constraints, changes in the capital income tax rates try to emulate the insurance provided by debt returns in models with debt. In these models, 
Figure 1: IRFs after one percent positive productivity shock.
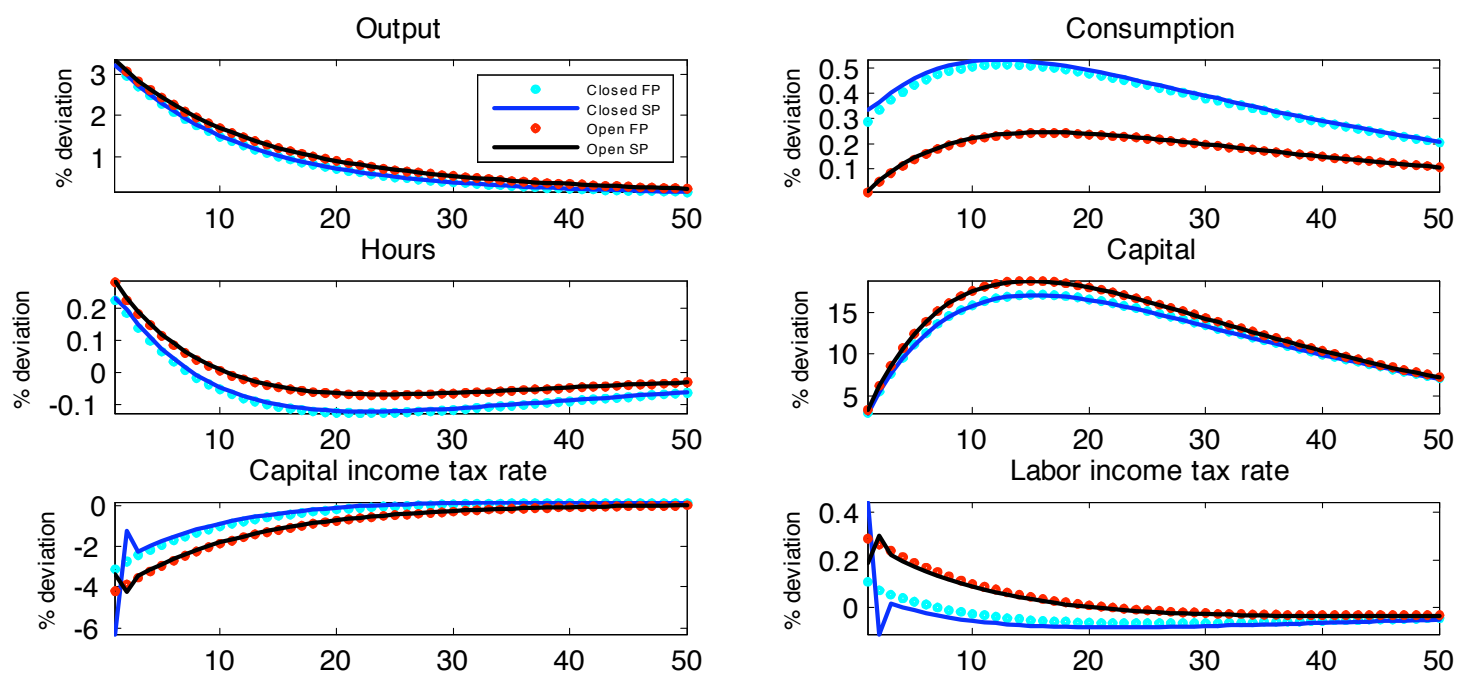

CPI-based real interest rate
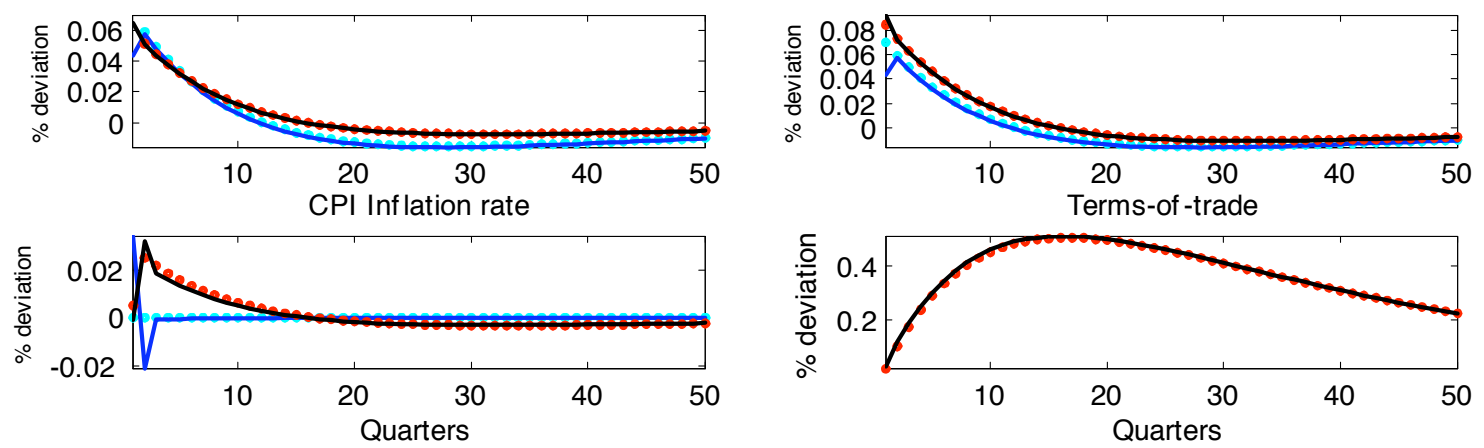
after a positive productivity shock, both tax rates are kept almost constant and debt decreases, acting as a shock absorber. Therefore, agents allocate more wealth to private assets (capital) and the latter rise significantly. In a balanced-budget model, this increase in private assets (physical capital) is emulated with a sustained drop in capital income taxes. This argument clearly applies to our framework. The drop in capital income taxes is large enough to require a slight increase in labor income taxes. The magnitude of the latter is limited since this tax rate is large in the steady state, which implies that small variations of the rate have large effects on the government's fiscal receipts.

Comparing the dynamics in a closed economy with sticky vs. flexible prices shows that the optimal policy under sticky prices actually seeks to replicate the flexible prices equilibrium, a result made standard by the literature on monetary policy initiated by Woodford (2003) among others. In a balanced-budget framework, the optimal tax system under sticky prices differs from the optimal tax system under flexible prices for 2 periods only, and both dynamics are identical from period 3 and onwards. After a productivity shock, PPI inflation increases in the first period and decreases in the second period, while tax rates adjust to stabilize the real marginal cost quickly. The objective is to stabilize the marginal cost as quickly as possible, while minimizing the distortions on labor and consumption decisions implied by sticky prices. In particular, the paths of consumption and hours are made almost perfectly identical under flexible and sticky prices by the central planner. The fact that tax rates react aggressively is thus to be related with the result of Correia et al. (2008) according to which under sticky prices with debt, a tax system allowing to replicate flexible prices allocations always exists. In our framework, however, the perfect replication of allocations, i.e. of quantities, is made impossible by the absence of debt, although the allocations under sticky prices only differ marginally from allocations under flexible prices.

The open economy plays a more interesting role, since it affects allocations for several periods. First, as foreign consumption is exogenous and constant, the risk sharing condition induces a direct relation between consumption and terms of trade. In the case of a positive productivity shock, as consumption increases, terms of trade increase (worsen) to deflate the wealth of domestic households and inflate that of foreign households. As in the open economy the CPI differs from the PPI, and as it incorporates the relative price 
of foreign goods, an increase in terms of trade results in an increase in the CPI. The latter has three important consequences when considering an open economy: $(i)$ the increase in consumption is much lower, $(i i)$ in order to smooth consumption, households increase their labor supply by more than in the closed economy case, and (iii) the relative price of capital goods (with respect to consumption goods) drops. Therefore, the increase in consumption is much lower while the increases in labor supply and in capital accumulation are both higher. The optimal tax system is qualitatively the same in the open economy (increase the labor income tax rate and lower the capital income tax rate), but movements in tax rates are both larger and more persistent. In particular, a larger increase in the labor income tax rate is able to limit the additional increase in labor supply triggered by the depreciation of terms of trade.

Similar mechanisms are at work in the case of a positive exogenous public spending shock, depicted in Figure 2.

A public spending shock has standard effects as an increase in output and hours is observed, while both capital accumulation and consumption drop due to crowding out effects. The optimal combination of tax rates consists in rising the capital income tax rate, and in decreasing the tax rate on labor income. In a closed economy, this pattern arises because the central planner tries to replicate the drop in private assets (capital) observed in models with debt, where debt increases significantly to absorb the shock and the stock of private assets shrinks. In our balanced-budget framework, a comparable decrease in private assets is reached with a large increase in capital income taxes, large enough to allow labor income taxes to drop, although modestly.

Again in this case, the presence of sticky prices does not have a significant impact on resulting optimal allocations, whereas openness matters quantitatively. Indeed, the drop in private consumption drives the terms of trade down (terms of trade improve), and domestic households enjoy a larger purchasing power, therefore reducing the size of the drop in private consumption. Because terms of trade improve, the relative price of capital goods increase (as shown by the difference between the CPI-based real interest rate and the PPI-based interest rate), inducing a shift in private expenditure from capital to consumption goods, and amplifies the drop in capital accumulation. The open economy 
Figure 2: IRFs after a one percent positive public spending shock.
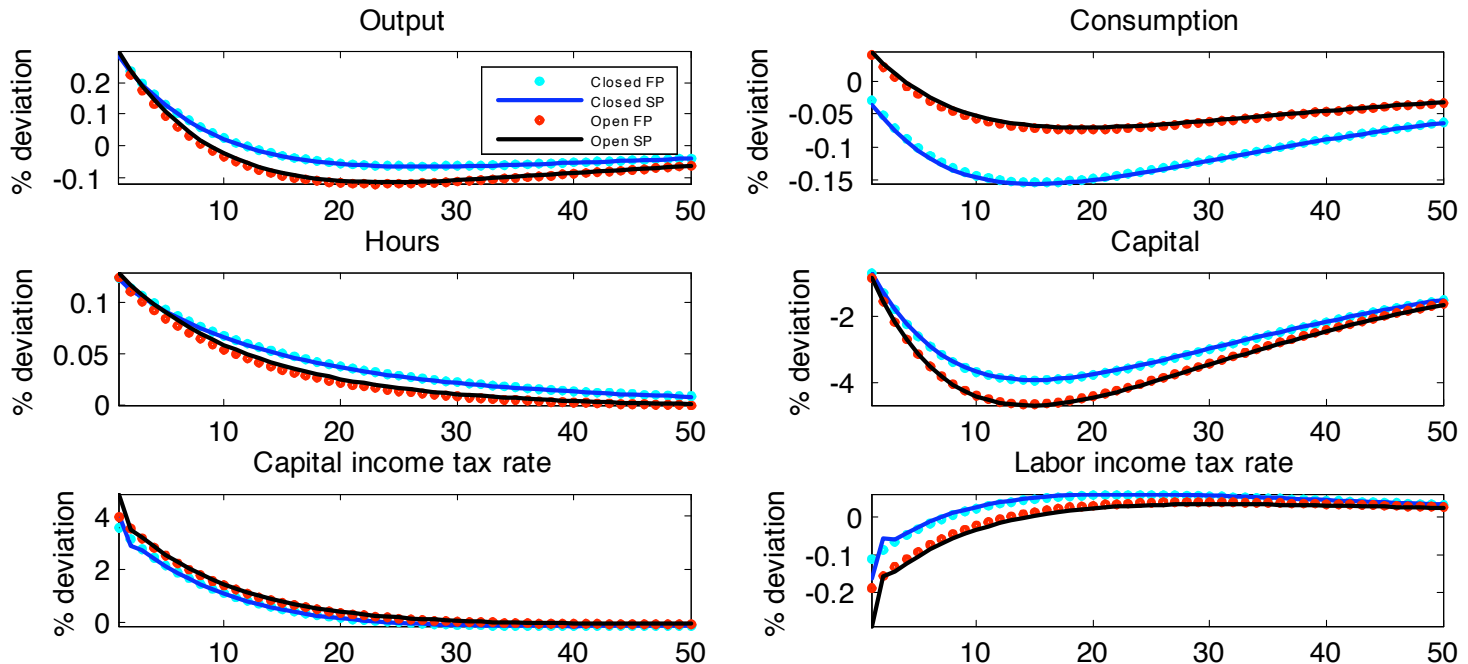

CPI-based real interest rate

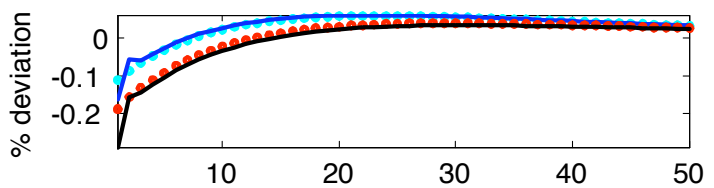

PPI-based real interest rate
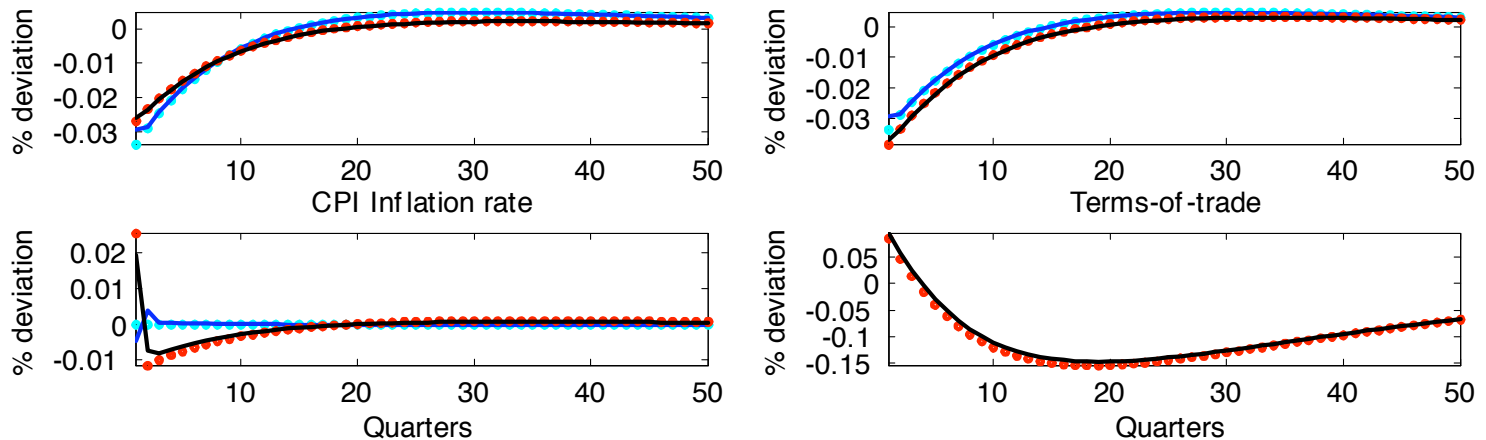
also deeply affects the response of labor supply. The CPI-based real wage increases, and households tend to decrease their labor supply. The government has to lower labor income taxes by more than in the case of a closed economy to undo the distortion between the marginal utility of consumption and the marginal disutility of labor implied by variations in terms of trade. As in the case of productivity shocks, changes in tax rates are larger than in a closed economy.

In a nutshell, the IRFs show that both sticky prices and the open economy have qualitatively similar implications in terms of dynamics under Ramsey policies. However, while sticky prices do not seem to matter a lot quantitatively, openness affects significantly the dynamics of the economy as compared to the case of a closed economy. To confirm these results, Table 2 provides some simulation-based results summarizing the main characteristics of optimal policies under the four considered situations.

First, Table 2 shows that tax rates are more volatile in the case of sticky prices. Stabilizing the distortions implied by sticky prices is achieved by movements in tax rates and not by movements in the nominal interest rate. As a matter of fact, the latter exhibits very little volatility, and this volatility is almost unaffected by the various assumptions. This result is thus closely related to that of Correia et al. (2008). Changes in tax rates are larger than when prices are flexible but in initial periods only. Consequently, their persistence collapses in comparison to the flexible price equilibrium. Second, compared to the effect of sticky prices, openness makes a larger difference, both in terms of volatility and persistence of tax rates. In an open economy, tax rates are systematically more volatile - conditionally on the assumption made on prices (sticky vs. flexible) - and more persistent. The mechanisms behind the larger volatility and persistence of tax rates relate to movements in terms of trade that $(i)$ alter the dynamics of private consumption by affecting the CPI inflation rate, $(i i)$ induce shifts between expenditure in capital goods and consumption goods by creating a wedge between the CPI-based and the PPI-based real interest rates, and (iii) affect labor supply decisions through terms of trade spillovers. ${ }^{8}$

\footnotetext{
${ }^{8}$ Some sensitivity analysis (not reported) shows that our results are qualitatively robust to changes in preference parameters, with marginal quantitative changes.
} 
Table 2: Characteristics of the optimal policies

\begin{tabular}{lrrrr}
\hline \hline & I & \multicolumn{1}{c}{ II } & \multicolumn{1}{c}{ III } & \multicolumn{1}{c}{ IV } \\
\hline \hline Capital income tax rate $\left(\tau_{k, t}\right)$ & & & & \\
Mean & 0.0000 & 0.0000 & 0.0000 & 0.0000 \\
Standard deviation & 0.0533 & 0.0631 & 0.0635 & 0.0664 \\
Autocorrelation & 0.6875 & 0.3687 & 0.6938 & 0.6459 \\
Correlation with output & -0.4071 & -0.4324 & -0.4967 & -0.4295 \\
Correlation with productivity & -0.5205 & -0.5384 & -0.5992 & -0.5397 \\
Correlation with public spending & 0.8525 & 0.7411 & 0.7999 & 0.8278 \\
\hline Ex-ante capital income tax rate & & & & \\
Mean & 0.0000 & 0.0000 & 0.0000 & 0.0000 \\
Standard deviation & 0.0418 & 0.0405 & 0.0515 & 0.0514 \\
Autocorrelation & 0.6900 & 0.6898 & 0.6936 & 0.6936 \\
Correlation with $\tau_{k, t}$ & 0.6895 & 0.4527 & 0.6945 & 0.6593 \\
Correlation with output & -0.3028 & -0.2870 & -0.3740 & -0.3588 \\
Correlation with productivity & -0.3677 & -0.3516 & -0.4225 & -0.4119 \\
Correlation with public spending & 0.6000 & 0.6112 & 0.5490 & 0.5567 \\
\hline Labor income tax rate $\left(\tau_{\ell, t}\right)$ & & & & \\
Mean & 0.3906 & 0.3906 & 0.3906 & 0.3906 \\
Standard deviation & 0.0018 & 0.0037 & 0.0036 & 0.0040 \\
Autocorrelation & 0.6873 & -0.0897 & 0.6985 & 0.5924 \\
Correlation with $\tau_{k, t}$ & -0.9468 & -0.8472 & -0.9766 & -0.9817 \\
Correlation with output & 0.3776 & 0.3098 & 0.6427 & 0.4871 \\
Correlation with productivity & 0.4979 & 0.3901 & 0.7367 & 0.5935 \\
Correlation with public spending & -0.7863 & -0.4198 & -0.6663 & -0.7446 \\
\hline Real or nominal interest rate ${ }^{a}$ & & & & \\
Mean & 1.0121 & 1.0121 & 1.0121 & 1.0121 \\
Standard deviation & 0.0008 & 0.0006 & 0.0009 & 0.0009 \\
Autocorrelation & 0.6893 & 0.8033 & 0.6885 & 0.6303 \\
Correlation with $\tau_{\ell, t}$ & -0.9055 & -0.6869 & -0.9313 & -0.8538 \\
Correlation with $\tau_{k, t}$ & 0.8972 & 0.2716 & 0.9815 & 0.8554 \\
Correlation with output & 0.7260 & 0.6233 & 0.7492 & 0.7678 \\
Correlation with productivity & 0.8124 & 0.7026 & 0.8333 & 0.8515 \\
Correlation with public spending & -0.5592 & -0.5960 & -0.5418 & -0.4939 \\
\hline \hline I: Cosed & & & & \\
\hline
\end{tabular}

I: Closed economy and flexible prices / II: Closed economy and sticky prices III: Open economy and flexible prices / IV: Open economy and sticky prices $a$ : In the case of flexible prices, the nominal rate is also the real rate since $\pi_{t}=0, \forall t$. 


\section{Conclusion}

This paper contributes to a growing literature on optimal monetary and fiscal policy. In a small open economy with sticky prices and capital, we compute the optimal Ramsey policy. We show that sticky prices have little impact on optimal allocations in the sense that optimal policies under sticky prices are designed to replicate allocations under flexible prices. On the contrary, openness matters both in the steady state and in terms of dynamics. The main results are as follows:

- Taxes are the preferred policy instrument to deal with nominal rigidities in the economy, not the nominal interest rate. The assumption of sticky prices affects the optimal dynamics of tax rates during the first periods after a shock, but corresponding allocations under sticky prices are almost indistinguishable from those arising in a flexible price equilibrium. This result hold both in a closed and in an open economy. Optimal policies under sticky prices thus induce more volatility in tax rates, but sharp movements in the first periods drive their persistence down.

- The open economy has larger and more persistent effects on the optimal dynamics of tax rates. The inclusion of international trade in goods and assets induces movements in terms of trade, that affect the economy through the implied disconnection between the CPI and the PPI. Consumption, capital accumulation and labor supply are affected all together, and although optimal movements in tax rates are qualitatively similar to those obtained in a closed economy set-up, significant quantitative differences arise. Open economy allocations are quite different from closed economy allocations, even when the steady state considered when the economy is open is isomorphic to that of a closed economy.

This paper is a first attempt to characterize optimal fiscal and monetary policy in an open economy set-up with sticky prices and capital accumulation. Due to the complexity of the model, we are not able to derive analytical results, which calls for further investigations. The analysis also imposes balanced-budget restrictions and abstracts from debt issues. These may be considered as an interesting extension to provide policymakers with more accurate policy recommendations. 


\section{References}

Backus, D. K. \& Kehoe, P. J. (1994), 'Dynamics of the Trade Balance and the Terms of Trade: The J-Curve?', American Economic Review 84(1), 84-103.

Benigno, G. \& Benigno, P. (2003), 'Price Stability in Open Economies', Review of Economic Studies 70(4), 743-764.

Benigno, G. \& de Paoli, B. (2010), 'On the International Dimension of Fiscal Policy', Journal of Money, Credit and Banking 42(8), 1523-1542.

Benigno, P. \& Woodford, M. (2005), 'Optimal Taxation in an RBC Model: A LinearQuadratic Approach', NBER Working Papers No 11029.

Calvo, G. (1983), 'Staggered Prices in a Utility-maximizing Framework', Journal of Monetary Economics 12(3), 383-398.

Canzoneri, M., Cumby, R. \& Diba, B. (2007), 'The Cost of Nominal Inertia in NNS Models', Journal of Money, Credit and Banking 39(7), 1563-1586.

Chamley, C. (1986), 'Optimal Taxation of Capital Income in General Equilibrium with Infinite Lives', Econometrica 54(3), 607-622.

Chari, V. V., Christiano, L. \& Kehoe, P. J. (1991), 'Optimal Fiscal and Monetary Policy: Some Recent Results', Journal of Money, Credit and Banking 23(3), 519-539.

Chari, V. V. \& Kehoe, P. J. (1999), Optimal Fiscal and Monetary Policy, in J. B. Taylor \& M. Woodford, eds, 'Handbook of Macroeconomics', Vol. 1, Elsevier, chapter 26, pp. 1671-1745.

Chari, V. V., Kehoe, P. J. \& McGrattan, E. R. (2002), 'Can Sticky Price Models Generate Volatile and Persistent Real Exchange Rates', Review of Economic Studies 69(3), 533563.

Correia, I., Nicolini, J. P. \& Teles, P. (2008), 'Optimal Fiscal and Monetary Policy: Equivalence Results', Journal of Political Economy 116(1), 141-170.

Corsetti, G. (2006), 'Openness and the Case for Flexible Exchange Rates', Research in Economics 60(1), 1-21.

Corsetti, G., Dedola, L. \& Leduc, S. (2008), 'High Exchange-rate Volatility and Low Pass-through', Journal of Monetary Economics 55(6), 1113-1128.

Corsetti, G. \& Pesenti, P. (2001), 'Welfare and Macroeconomic Interdependence', Quarterly Journal of Economics 116(2), 421-445.

Corsetti, G. \& Pesenti, P. (2005), 'International Dimensions of Optimal Monetary Policy', Journal of Monetary Economics 52(2), 281-305. 
de Paoli, B. (2009), 'Monetary Policy and Welfare in a Small Open Economy', Journal of International Economics 77(1), 11-22.

Devereux, M. B. \& Engel, C. (2007), 'Expenditure Switching versus Real Exchange Rate Stabilization: Competing Objectives for Exchange Rate Policy', Journal of Monetary Economics 54(8), 2346-2374.

Dixit, A. \& Stiglitz, J. (1977), 'Monopolistic Competition and Optimum Product Diversity', American Economic Review 67(3), 297-308.

Ferrero, A. (2009), 'Fiscal and Monetary Rules for a Currency Union', Journal of International Economics 77(1), 1-10.

Galí, J. \& Monacelli, T. (2005), 'Monetary Policy and Exchange Rate Volatility in a Small Open Economy', Review of Economic Studies 72(3), 707-734.

Galí, J. \& Monacelli, T. (2008), 'Optimal Monetary and Fiscal Policy in a Currency Union', Journal of International Economics 76(1), 116-132.

Goldberg, L. \& Tille, C. (2008), 'Macroeconomic Interdependence and the International Role of the Dollar', NBER Working Paper No 13820 .

Klein, P. \& Rios-Rull, J.-V. (2003), 'Time-consistent Optimal Fiscal Policy', International Economic Review 44(4), 1217-1245.

Lucas, R. \& Stokey, N. (1983), 'Optimal Fiscal and Monetary Policy in an Economy without Capital', Journal of Monetary Economics 12(1), 55-93.

Obstfled, M. \& Rogoff, K. (1998), Risk and Exchange Rates, Working Paper 6694, NBER.

Pappa, E. \& Vassilatos, V. (2007), 'The Unbearable Tightness of Being in a Monetary Union: Fiscal Restrictions and Regional Stability', European Economic Review 51(6), 1492-1513.

Rotemberg, J. \& Woodford, M. (1997), An Optimization-based Econometric Framework for the Evaluation of Monetary Policy, in B. S. Bernanke \& J. J. Rotemberg, eds, 'NBER Macroeconomics Annual'.

Schmitt-Grohe, S. \& Uribe, M. (2004), 'Optimal Fiscal and Monetary Policy under Sticky Prices', Journal of Economic Theory 114(2), 198-230.

Stockman, D. R. (2001), 'Balanced-budget Rules: Welfare Loss and Optimal Policies', Review of Economic Dynamics 4(2), 438-459.

Sutherland, A. (2006), 'The Expenditure Switching Effect, Welfare and Monetary Policy in a Small Open Economy', Journal of Economic Dynamics and Control 30(7), 11591182. 
Woodford, M. (2000), 'Pitfalls of Forward-looking Monetary Policy', American Economic Review Papers and Proceedings 90(1), 100-104.

Woodford, M. (2003), Interest and Price, Princeton University Press. 


\section{A Recursive formulation of pricing conditions}

Putting price setting behavior in a recursive problem, we start from:

$$
\begin{gathered}
\frac{\bar{p}_{t}(i)}{p_{t}}=\frac{\theta}{\theta-1} \frac{p_{1, t}}{p_{t} p_{2, t}}, \\
p_{1, t}=\sum_{v=0}^{\infty}(\eta \beta)^{v} E_{t}\left\{\lambda_{t+v} y_{t+v}(i) m c_{t+v}\right\}, \\
p_{2, t}=\sum_{v=0}^{\infty}(\eta \beta)^{v} E_{t}\left\{\lambda_{t+v} y_{t+v}(i)\right\} .
\end{gathered}
$$

Using $y_{t}(i)=\left(\frac{p_{t}(i)}{p_{t}}\right)^{-\theta} y_{t}$ and $\lambda_{t}=\frac{u_{c, t}}{p_{c, t}}$ :

$$
\begin{gathered}
p_{1, t}=\sum_{v=0}^{\infty}(\eta \beta)^{v} E_{t}\left\{\frac{u_{c, t+v}}{p_{c, t+v}} p_{t+v}^{\theta} y_{t+v} m c_{t+v}\right\}, \\
p_{2, t}=\sum_{v=0}^{\infty}(\eta \beta)^{v} E_{t}\left\{\frac{u_{c, t+v}}{p_{c, t+v}} p_{t+v}^{\theta} y_{t+v}\right\},
\end{gathered}
$$

and using a recursive transformation:

$$
\begin{gathered}
p_{1, t}-\eta \beta E_{t}\left\{p_{1, t+1}\right\}=u_{c, t} \frac{p_{t}^{\theta}}{p_{c, t}} y_{t} m c_{t}, \\
p_{2, t}-\eta \beta E_{t}\left\{p_{2, t+1}\right\}=u_{c, t} \frac{p_{t}^{\theta}}{p_{c, t}} y_{t} .
\end{gathered}
$$

Finally, defining

$$
v_{1, t}=\frac{p_{1, t} p_{c, t}}{p_{t}^{1+\theta}}, \text { and } v_{2, t}=\frac{p_{2, t} p_{c, t}}{p_{t}^{\theta}}
$$

we get

$$
\frac{\bar{p}_{t}}{p_{t}}=\frac{\theta}{\theta-1} \frac{v_{1, t}}{v_{2, t}}
$$

where

$$
\begin{gathered}
v_{1, t}-\eta \beta E_{t}\left\{v_{1, t+1} \pi_{t+1}^{1+\theta} \pi_{c, t+1}^{-1}\right\}=u_{c, t} y_{t} \frac{m c_{t}}{p_{t}} \\
v_{2, t}-\eta \beta E_{t}\left\{v_{2, t+1} \pi_{t+1}^{\theta} \pi_{c, t+1}^{-1}\right\}=u_{c, t} y_{t} .
\end{gathered}
$$

\section{B Summary of equilibrium conditions}

Equilibrium conditions are expressed in real terms. We therefore define the real wage as $\omega_{t}=\frac{w_{t}}{p_{t}}$, and real capital rental as $\zeta_{t}=\frac{z_{t}}{p_{t}}$. 
Labour supply

$$
-\frac{u_{\ell, t}}{u_{c, t}}=\left(1-\tau_{\ell, t}\right) \omega_{t}\left(1-\alpha+\alpha s_{t}^{1-\mu}\right)^{\frac{1}{\mu-1}} .
$$

Euler equation

$$
1=r_{t} \beta E_{t}\left\{\frac{u_{c, t+1}}{\pi_{c, t+1} u_{c, t}}\right\} .
$$

Arbitrage between physical and financial assets

$$
r_{t}=E_{t}\left\{\pi_{t+1}\left(1+\left(1-\tau_{k, t+1}\right)\left(\zeta_{t+1}-\delta\right)\right)\right\} .
$$

Risk-sharing condition

$$
\frac{u_{c^{*}, t}^{*}}{u_{c, t}}=\epsilon\left(\alpha+(1-\alpha) s_{t}^{\mu-1}\right)^{\frac{1}{\mu-1}} .
$$

Consumer prices index inflation

$$
\pi_{c, t}=\pi_{t}\left(\frac{1-\alpha+\alpha s_{t}^{1-\mu}}{1-\alpha+\alpha s_{t-1}^{1-\mu}}\right)^{\frac{1}{1-\mu}} .
$$

Production prices inflation

$$
\begin{gathered}
\eta \pi_{t}^{\theta-1}+(1-\eta)\left(\frac{v_{1, t}}{v_{2, t}}\right)^{1-\theta}=1, \\
v_{1, t}=\eta \beta E_{t}\left\{v_{1, t+1} \pi_{t+1}^{1+\theta} \pi_{c, t+1}^{-1}\right\}+u_{c, t} y_{t} \frac{m c_{t}}{p_{t}} \\
v_{2, t}=\eta \beta E_{t}\left\{v_{2, t+1} \pi_{t+1}^{\theta} \pi_{c, t+1}^{-1}\right\}+u_{c, t} y_{t} .
\end{gathered}
$$

Production prices dispersion

$$
\Upsilon_{t}=\eta \Upsilon_{t-1} \pi_{t}^{\theta}+(1-\eta)\left(\frac{v_{1, t}}{v_{2, t}}\right)^{-\theta}
$$

Marginal cost and inputs efficiency

$$
\begin{aligned}
& \frac{m c_{t}}{p_{t}}=\frac{\zeta_{t}^{\phi} \omega_{t}^{1-\phi}}{\phi^{\phi}(1-\phi)^{1-\phi}} a_{t}^{-1}, \\
& \phi \omega_{t} \ell_{t}=(1-\phi) \zeta_{t} k_{t-1} .
\end{aligned}
$$

Aggregate production function

$$
y_{t} \Upsilon_{t}=a_{t} k_{t-1}^{\phi} \ell_{t}^{1-\phi}
$$

Goods markets clearing condition

$$
y_{t}=(1-\alpha)\left(1-\alpha+\alpha s_{t}^{1-\mu}\right)^{\frac{\mu}{1-\mu}} c_{t}+\alpha s_{t}^{\mu} c_{t}^{*}+k_{t}-(1-\delta) k_{t-1}+g_{t} .
$$

Government budget constraint

$$
\tau_{\ell, t} \omega_{t} \ell_{t}+\tau_{k, t}\left(\zeta_{t}-\delta\right) k_{t-1}=g_{t}
$$




\section{Some steady state relations}

The steady state of the economy is given by assuming $a=1$ and $g=\kappa y$. First, The definition of CPI inflation gives $\pi_{c}=\pi$ always. From the Euler equation, we get

$$
\beta^{-1}=\frac{r}{\pi}
$$

The arbitrage condition between assets yields

$$
\zeta=\frac{\beta^{-1}-1}{1-\tau_{k}}+\delta
$$

which determines $\zeta$ conditionally on $\tau_{k}$. Normalizing $p=1$ due to the absence of money in the model, marginal cost and input efficiency imply

$$
\begin{gathered}
\zeta=m c \phi\left(\frac{k}{\ell}\right)^{\phi-1}, \\
\omega=\frac{(1-\phi)}{\phi} \frac{k}{\ell} \zeta=(1-\phi) m c\left(\frac{k}{\ell}\right)^{\phi},
\end{gathered}
$$

which determines $\omega$ and the capital-labor ratio once $m c$ and $\tau_{k}$ are determined. Indeed,

$$
\frac{k}{\ell}=\left(\frac{\left(\beta^{-1}-1\right)\left(1-\tau_{k}\right)^{-1}+\delta}{\phi m c}\right)^{\frac{1}{\phi-1}}=h\left(\tau_{k}, m c\right),
$$

Pricing conditions imply

$$
\begin{gathered}
m c=\left(\frac{1-\eta \pi^{\theta-1}}{1-\eta}\right)^{\frac{1}{1-\theta}} \frac{1-\eta \beta \pi^{\theta}}{1-\eta \beta \pi^{\theta-1}}, \\
\Upsilon=\frac{(1-\eta)}{\left(1-\eta \pi^{\theta}\right)}\left(\frac{1-\eta \pi^{\theta-1}}{1-\eta}\right)^{\frac{\theta}{\theta-1}}
\end{gathered}
$$

which uniquely determines $m c$ and $\Upsilon$ once $\pi$ is known. We thus denote these functions as $m c(\pi)$ and $\Upsilon(\pi)$.

The risk sharing condition determines $s$ once $c$ is known, since $c^{*}$ is exogenous. Thus we use

$$
s=\left((1-\alpha)^{-1}\left(\left(\frac{c}{c^{*}}\right)^{\sigma(\mu-1)}-\alpha\right)\right)^{\frac{1}{\mu-1}} .
$$

Using the aggregate production function $y=\Upsilon(\pi)^{-1}\left(\frac{k}{\ell}\right)^{\phi} \ell$, and the capital-labor ratio, the goods market clearing condition gives

$$
\left((1-\kappa) \Upsilon(\pi)^{-1} h\left(\tau_{k}, m c(\pi)\right)^{\phi}-\delta h\left(\tau_{k}, m c(\pi)\right)\right) \ell=c f_{3}(c),
$$


where

$$
\begin{gathered}
f_{3}(c)=(1-\alpha) f_{2}^{-\mu}+\alpha \frac{c^{*}}{c}\left((1-\alpha)^{-1}\left(\left(\frac{c}{c^{*}}\right)^{\sigma(\mu-1)}-\alpha\right)\right)^{\frac{\mu}{\mu-1}} \\
f_{2}(c)=\left((1-\alpha)\left(1+\alpha\left(\left(\frac{c}{c^{*}}\right)^{\sigma(\mu-1)}-\alpha\right)^{-1}\right)\right)^{\frac{1}{\mu-1}} .
\end{gathered}
$$

Using previous relations, the government budget constraint helps determining $\tau_{\ell}$ conditionally on $\left(\pi, \tau_{k}\right)$

$$
\tau_{\ell}\left(\tau_{k}, m c(\pi)\right)=\frac{\kappa \Upsilon(\pi)^{-1}-\tau_{k}\left(m c(\pi) \phi-\delta h\left(\tau_{k}, m c(\pi)\right)^{1-\phi}\right)}{(1-\phi) m c(\pi)} .
$$

Thus, labor supply writes

$$
\ell^{\psi} c^{\sigma}=\left(1-\tau_{\ell}\left(\tau_{k}, m c(\pi)\right)\right) m c(\pi)(1-\phi) h\left(\tau_{k}, m c(\pi)\right)^{\phi} f_{2}(c),
$$

or equivalently,

$$
\ell=c^{-\frac{\sigma}{\psi}}\left(\left(1-\tau_{\ell}\left(\tau_{k}, m c(\pi)\right)\right) m c(\pi)(1-\phi) h\left(\tau_{k}, m c(\pi)\right)^{\phi} f_{2}(c)\right)^{\frac{1}{\psi}} .
$$

Combining (20) and (21), we get $c$ as a function of $\left(\pi, \tau_{k}\right)$

$$
c^{\frac{\sigma+\psi}{\psi}} f_{2}(c)^{-\frac{1}{\psi}} f_{3}(c)=\chi_{1} \chi_{2}^{\frac{1}{\psi}}
$$

where

$$
\begin{gathered}
\chi_{1}=(1-\kappa) \Upsilon(\pi)^{-1} h\left(\tau_{k}, m c(\pi)\right)^{\phi}-\delta h\left(\tau_{k}, m c(\pi)\right) \\
\chi_{2}=\left(1-\tau_{\ell}\left(\tau_{k}, m c(\pi)\right)\right) m c(\pi)(1-\phi) h\left(\tau_{k}, m c(\pi)\right)^{\phi}
\end{gathered}
$$

All variables are determined conditionally on a certain policy in the steady state $\left(\pi, \tau_{k}\right)$, that is determined after solving dynamic conditions of the Ramsey problem. 